\title{
IMPLEMENTASI LESSON STUDY BERBASIS SEKOLAH (LSBS) DI SMP NEGERI 1 KALIANGET
}

\author{
Eko Wahjudi ${ }^{1}$, Tri Andayani ${ }^{2}$, \\ Ahmad Herman ${ }^{3}$, Enny Wijaya R A. ${ }^{4}$ \\ Pengajar SMP Negeri 1 Kalianget ${ }^{1,2,3,4}$ \\ ekowahjudi99@yahoo.com ${ }^{1}$
}

\begin{abstract}
ABSTRAK
Lesson studymerupakan salah satu upaya pembinaan untuk meningkatkan proses pembelajaran yang dilakukan oleh sekelompok guru secara kolaboratif dan berkesinambungan, dalam merencanakan, melaksanakan, mengobservasi dan melaporkan hasil pembelajaran. Di dalam pembelajaran, guru hanya berperan sebagai fasilitator. Penggerak utama pembelajaran adalah siswa itu sendiri. Siswa dituntut untuk lebih aktif dan mengambil peran dalam proses pembelajaran. Kegiatan lesson study terbagi menjadi 3 tahap yaitu 1) tahap perencanaan (plan) yaitu guru atau kelompok guru akan menyusun kegiatan pembelajaran yang akan dilaksanakan, 2) tahap pelaksanaan (do) yaitu seorang guru sebagai guru model untuk menyajikan pembelajaran sesuai perencanaan yang telah disusun dan guru yang lain melakukan pengamatan yang dilakukan oleh siswa, dan 3) tahap refleksi (see) dalam tahap ini mendiskusikan dari hasil pengamatan serta mencari penyelesaian masalah yang terjadi selama pembelajaran. Setelah melaksanakan lesson study guru diharapkan mampu memberikan inovasi dalam kegiatan pembelajaran,serta meningkatkan kualitas pembelajaran.
\end{abstract}

\section{Kata kunci : kegiatan pembelajaran, siswa aktif, lesson study}

\section{PENDAHULUAN}

Dalam penyajian pembelajaran masih banyak guru yang melakukan konsep pembelajaran satu arah dalam artian guru menyampaikan materi dengan harapan siswa bisa memahami materi tersebut seperti yang diinginkan olehnya tanpa memberi kesempatan untuk berinovasi, berkreasi dan kritis, sehingga dirasakan pelajaran kurang menantang untuk berpikir. Akibatnya siswa tidak menyenangi pelajaran.

Dari apa yang tersebut di atas sudah selayaknya guru merubah konsep pembelajaran satu arah menjadi pembelajaran konstruktivisme dalam artian guru tidak hanya semata-mata memberikan pengetahuan kepada siswa tetapi harus membangun pengetahuan didalam diri mereka.

Oleh karena itu diperlukan lesson study sebagai suatu kegiatan pembelajaran yang dapat dijadikan suatu bentuk acuan atau ukuran tentang sejauh penguasaan materi yang dimiliki guru, sejauh mana siswa terlibat secara aktif, sejauh mana ketepatan dalam memilih dan menggunakan media dan sumber belajar serta teknik dan instrumen penilaian yang dilakukan.

Implementasi lesson study berbasis sekolah (LSBS) di SMP Negeri 1 Kalianget bertujuan mendeskripsikan pelaksanaan Lesson StudyBerbasis Sekolah di SMP Negeri 1 Kalianget dan mengetahui manfaat Lesson Study Berbasis Sekolahdalam mengembangkan pembelajaran guru mengaktifkan siswa belajar.

\section{PEMBAHASAN}

Lesson Study bukanlah suatu strategi atau metode dalam pembelajaran, tetapi merupakan salah satu upaya pembinaan untuk meningkatkan proses pembelajaran yang dilakukan oleh sekelompok guru secara kolaboratif dan berkesinambungan, dalam merencanakan, melaksanakan, mengobservasi dan 
melaporkan

hasil

pembelajaran.(Sudrajat,A.2008)

Dalam implementasi Lesson Study yang dilakukan oleh IMSTEP-JICA di Indonesia, Saito, E.,dkk. (2005)mengenalkan Lesson Study yang ber-orientasi padapraktik yang dilaksanakan tersebut terdiri atas 3 tahap pokok, yakni:

\section{1) Perencanaan(Plan)}

Pada tahap ini dilakukan identifikasi masalah yang ada di kelas yang akan digunakan untuk kegiatan Lesson Study dan perencanaan alternatif pemecahannya. Identifikasi masalah dalam rangka perencanaan pemecahan masalah tersebut berkaitan dengan pokok bahasan (materi pelajaran) yang relevan dengan kelas dan jadwal pelajaran, karakteristik siswa dan suasana kelas, metode/pendekatan pembelajaran, media, alat peraga, dan evaluasi proses dan hasil belajar.

Dari hasil identifikasi masalah dan diskusi perencanaan pemecahannya, selanjutnya disusun dan dikemas dalam suatu perangkat pembelajaran yang terdiri atas :

a) Rencana Pelaksanaan Pembelajaran (RPP)

b) Lembar Kerja Siswa (LKS)

c) Media atau alat peraga pembelajaran

d) Instrumen penilaian proses dan hasil pembelajaran.

e) Lembar observasi pembelajaran.

Penyusunan perangkat pembelajaran ini dapat dilakukan oleh seorang guru atau beberapa orang guru atas dasar kesepakatan tentang aspek-aspek pembelajaran yang direncanakan sebagai hasil dari diskusi. Hasil penyusunan perangkat pembelajaran tersebut perlu dikonsultasikan dengan dosen atau guru yang dipandang pakar dalam kelompoknya untuk disempurnakan.

\section{2) Implementasi dan Observasi(DO)}

Pada tahap ini seorang guru yang telah ditunjuk (disepakati) oleh kelompoknya, melakukan implementasi rencana pelaksanaan pembelajaran (RPP) yang telah disusun tersebut, di kelas. Pakar dan guru lain melakukan observasi dengan menggunakan lembar observasi yang telah dipersiapkan dan perangkat lain yang diperlukan. Para observer ini mencatat hal-hal positif dan negatif dalam proses pembelajaran, terutama dilihat dari segi tingkah laku siswa. Selain itu (jika memungkinkan), dilakukan rekaman video (audio visual) yang mengclose-up kejadian-kejadian khusus (pada guru atau siswa) selama pelaksanaan pembelajaran. Hasil rekaman ini berguna nantinya sebagai bukti autentik kejadian-kejadian yang perlu didiskusikan dalam tahap refleksi atau pada seminar hasil Lesson Study, di samping itu dapat digunakan sebagai bahan diseminasi kepada khalayak yang lebih luas.

\section{Refleksi $(S E E)$}

Selesai praktik pembelajaran, segera dilakukan refleksi. Pada tahap refleksi ini, guru yang tampil dan para observer serta pakar mengadakan diskusi tentang pembelajaran yang baru saja dilakukan. Diskusi ini dipimpin oleh Kepala Sekolah, Koordinator kelompok, atau guru yang ditunjuk oleh kelompok.

Dalam mengimplementasikan Lesson Study Berbasis Sekolah (LSBS) di SMP Negeri 1 Kalianget terdapat kegiatan kegiatan sebagai berikut :

\section{Tahap Persiapan}

Pada tahap ini seorang guru model yang akan melakukan open class, mendata beberapa orang guru yang memiliki jam kosong saat kegiatan open class berlangsung untuk menjadi pengamat. Setelah mendapatkan data beberapa guru yang dimaksud tersebut, guru model menghadap kepada kepala sekolah untuk mengajukan permohonan akan melakukan kegiatan open class dengan rincian kegiatan sebagai berikut:

a. Menyusun Tim LSBS

Dalam tim ini terdiri dari :

Penanggung jawab(Kepala Sekolah), guru model, observer/pengamat, 
moderator, notulen, dokumenter foto, dan dokumenter video

b. Menyusun action plan sebagai berikut:

1) Tahap Plan

Kegiatan :

- Penyusunan RPP

- Menyusun LKS

- Penyusunan lembar observasi

- Penyusunan tata tertib kegiatan Open Class LS

- Penetapan jadwal pelaksanaan (DO) dan refleksi (SEE)

2) TahapPelaksanaan (DO)

Kegiatan :

- Pelaksanaan pembelajaran
- Pengamatan pelaksanaan pembelajaran

- Pengambilan dokumentasi foto dan video pelaksanaan pembelajaran

3) Tahap Refleksi (SEE)

Kegiatan :

- Penyampaian pengalaman guru model

- Penyampaian hasil pengamatan

- Evaluasi hasil pelaksanaan pembelajaran

- Penyusunan hasil refleksi dan langkah-langkah tindak lanjut

- Penyusunan Laporan dan Makalah

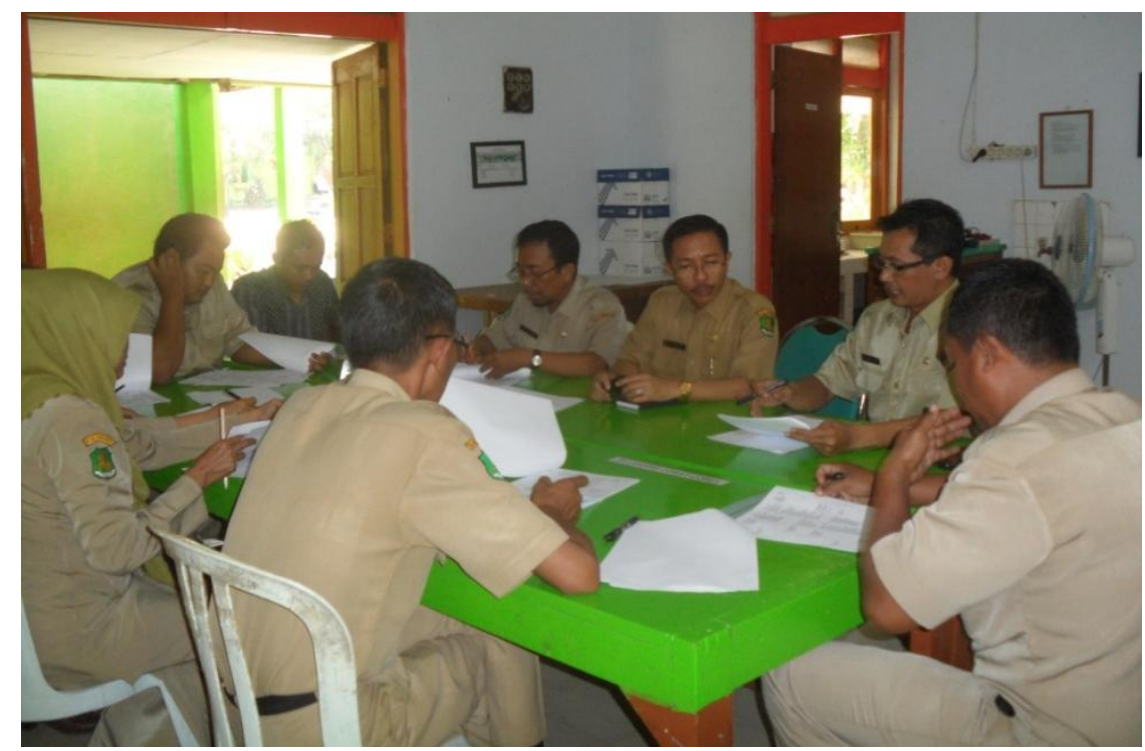

Gambar 1. Foto Kegiatan Tahap PLAN

\section{Tahap Perencanaan (Plan)}

Dalam kegiatan ini direncanakan akan menyajikan RPP di Kelas VIII - C dalam Pembelajaran IPA dengan Materi Cermin Cekung dan tempat pelaksanaan kegiatan open class di Laboratorium IPA SMP Negeri 1 Kalianget.

Setelah RPP (terlampir) tersusun dan disepakati dilanjutkan dengan menyusun dan menyepakati tata tertib kegiatanopen class yang bertujuan agar kegiatan ini tidak mengganggu jalannya proses belajar mengajar dan mendapatkan hasil pengamatan yang akurat dan optimal.

\section{Tahap Pelaksanaan $(D O)$}

Pada tahap ini guru menyajikan pembelajaran yang sudah disusun dalam RPP yang telah disepakati pada tahap sebelumnya atau dalam tahap Plan. Pada tahap pelaksanaan pembelajaran ini (tahap DO) guru menyajikan materi pembentukan bayangan pada cermin cekung dengan model pembelajaran Problem Based Learning (PBL). 


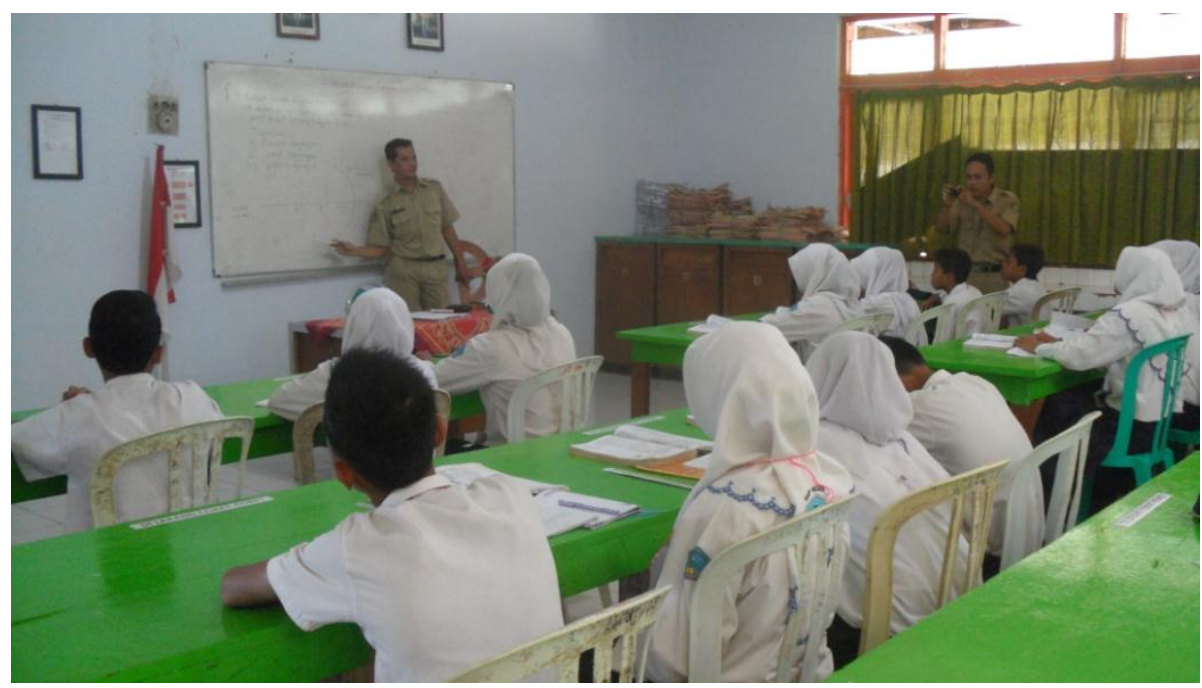

Gambar 2. Guru model memberikan orientasi masalah

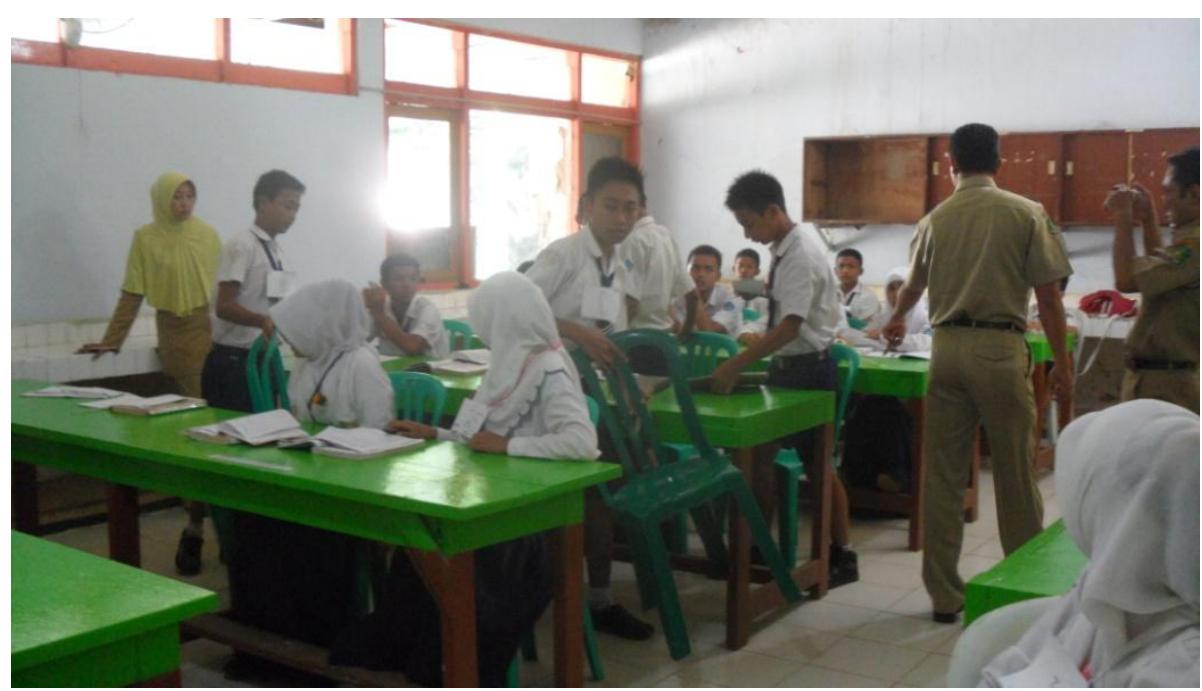

Gambar 3. Guru model mengorganisasikan peserta didik

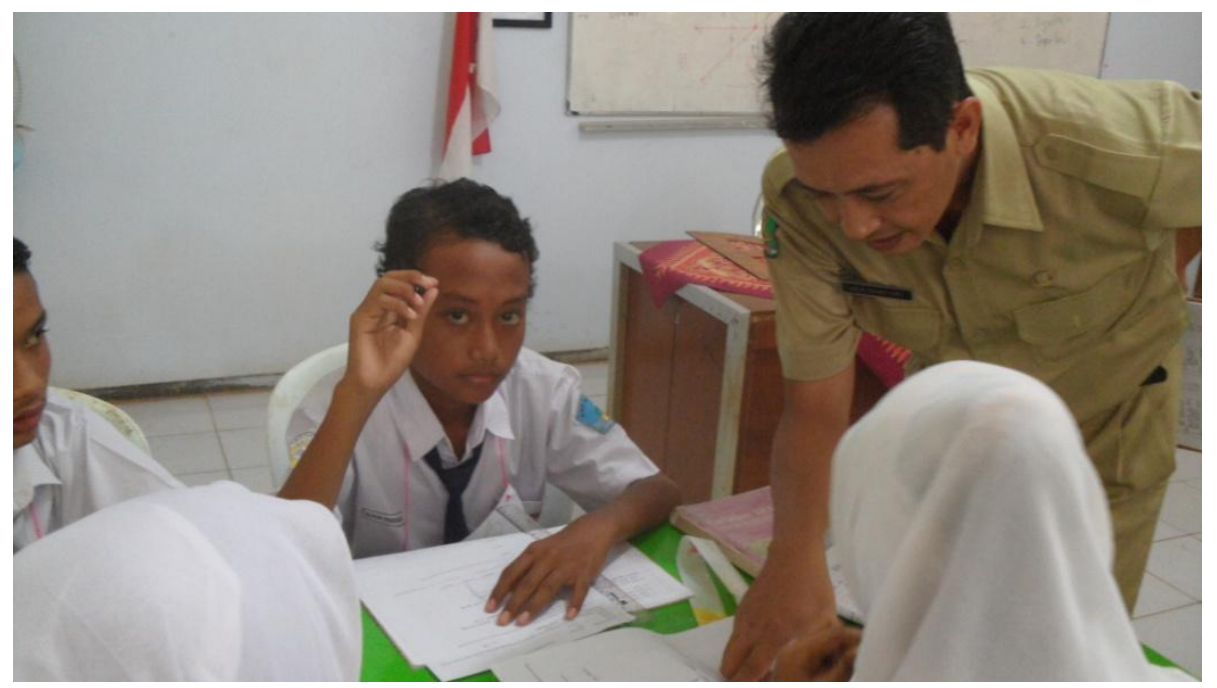

Gambar 4. Guru model membimbing penyelidikan individu dan kelompok 


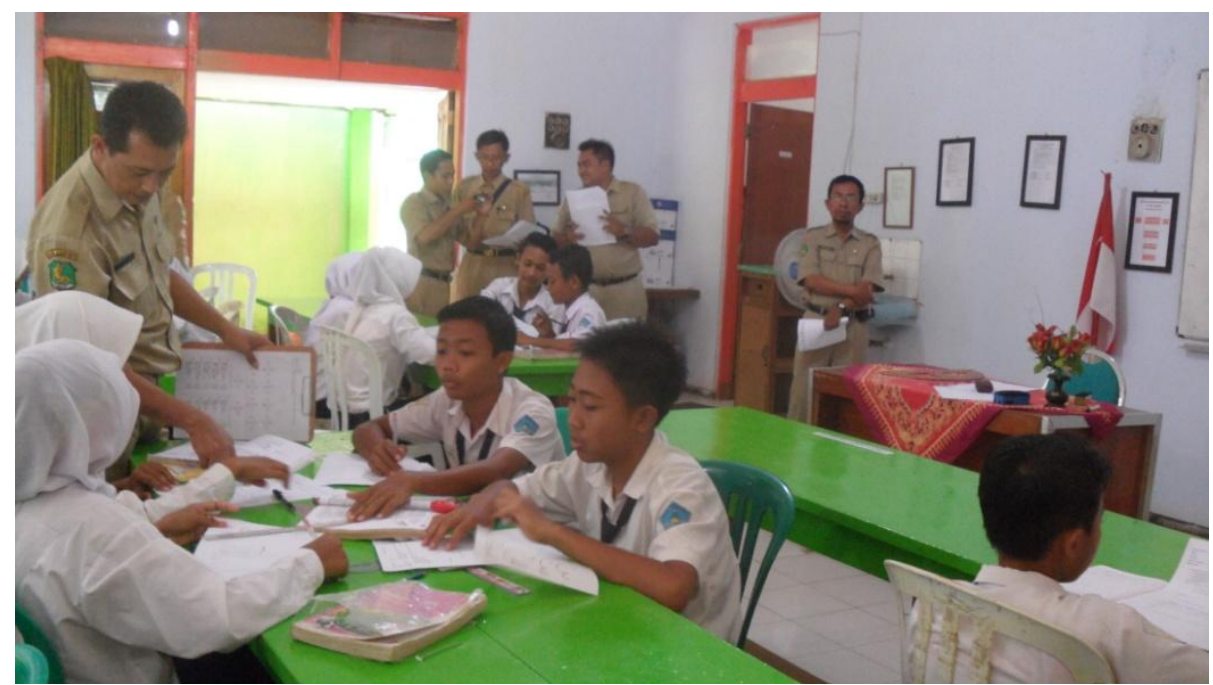

Gambar 5. Guru model mengembangkan dan menyajikan hasil karya

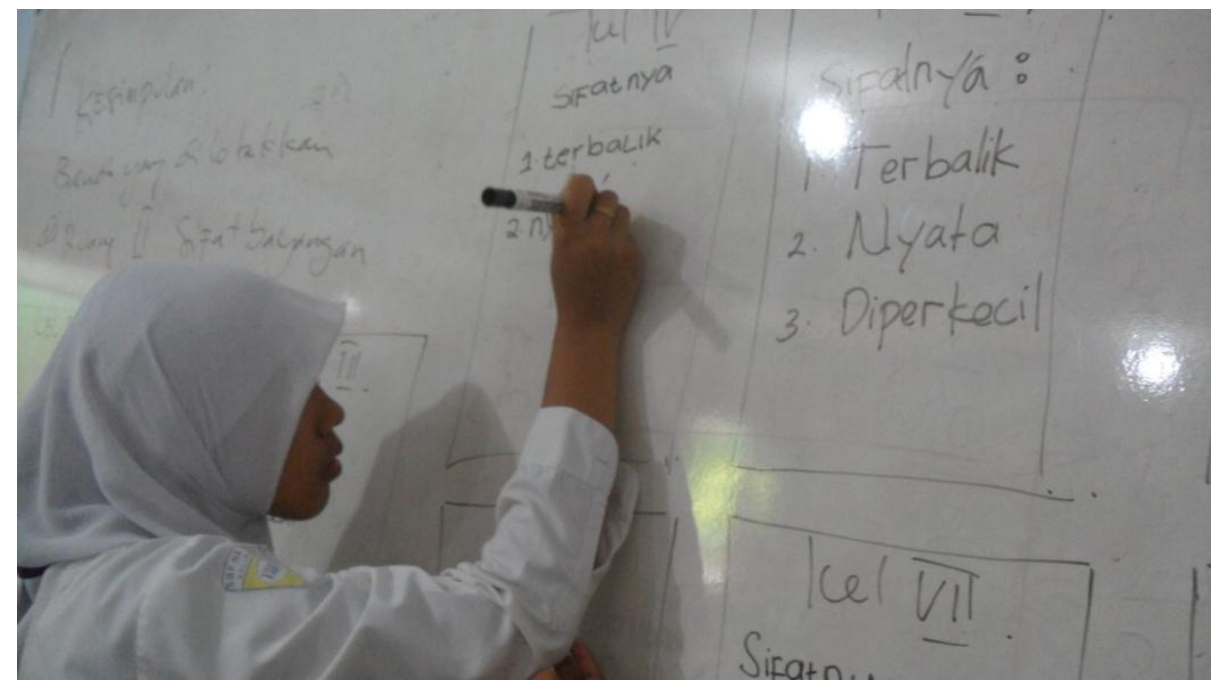

Gambar 6. Siswa menganalisa dan mengevaluasi proses pemecahan masalah

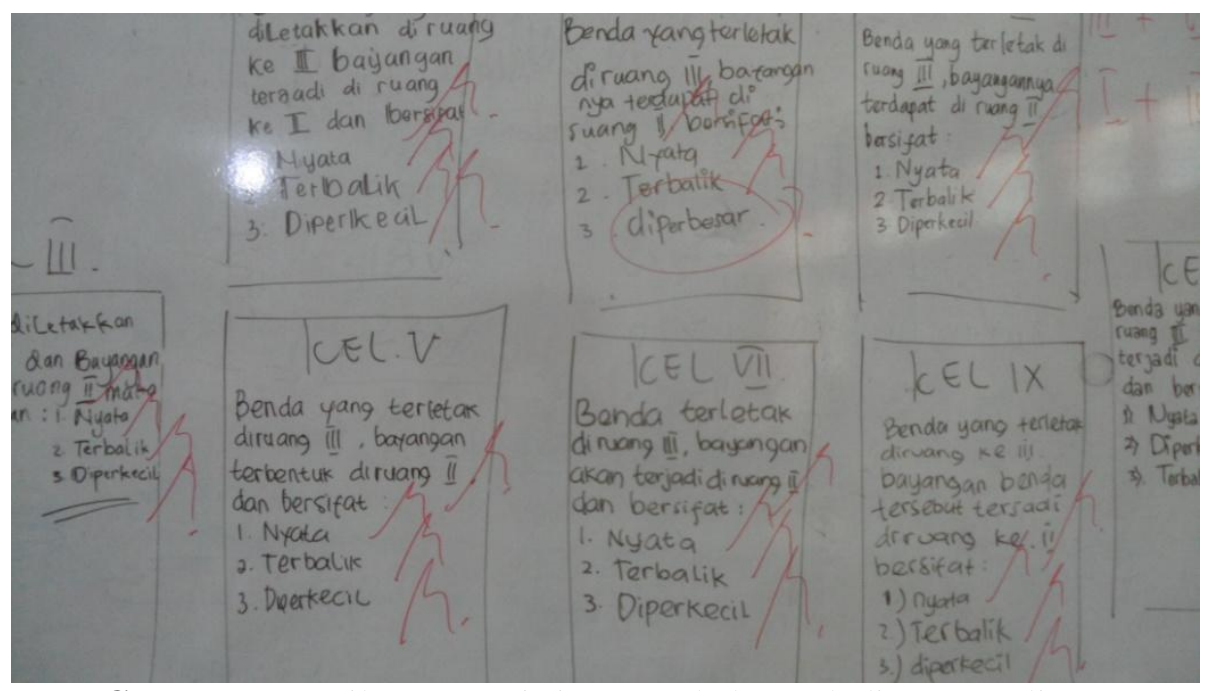

Gambar 7. Hasil presentasi siswa per kelompok di papan tulis 


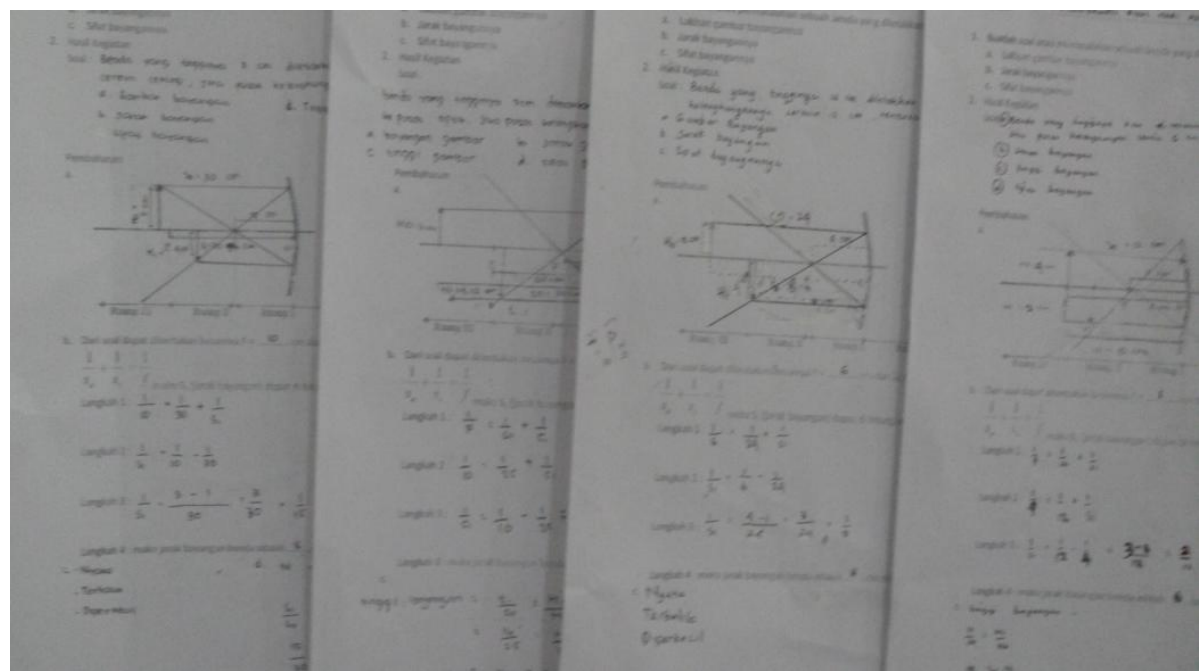

Gambar 8. Hasil presentasi siswa per individu

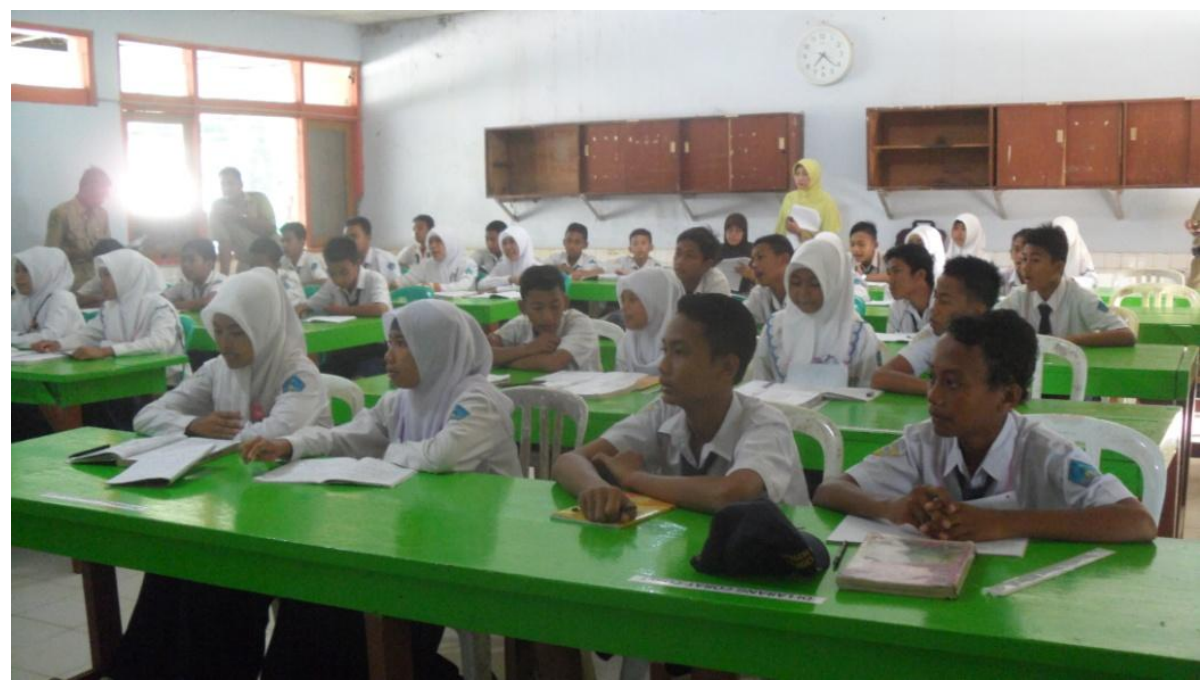

Gambar 9. Posisi pengamat

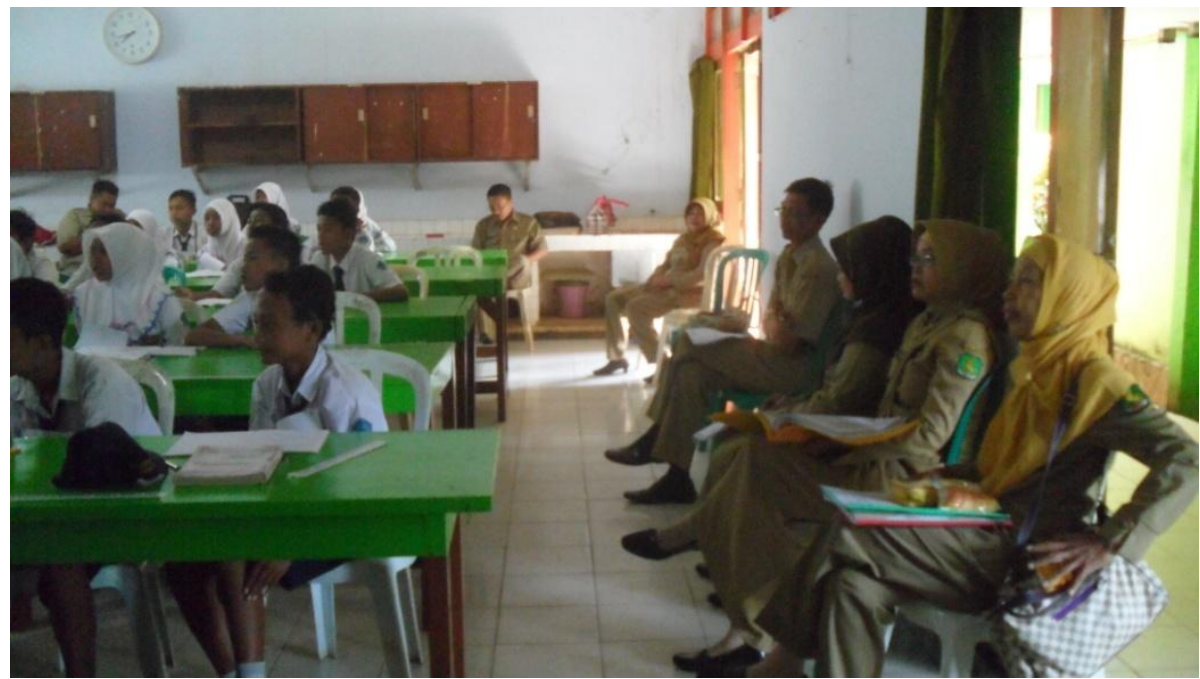

Gambar 10. Posisi pengamat

\section{Tahap Refleksi (SEE)}

Pada tahap ini dilakukan diskusi dari hasil pengamatan yang sudah dilakukan pada tahap DO, setiap pengamat dan guru model menyampaikan hasil pengamatannya. 


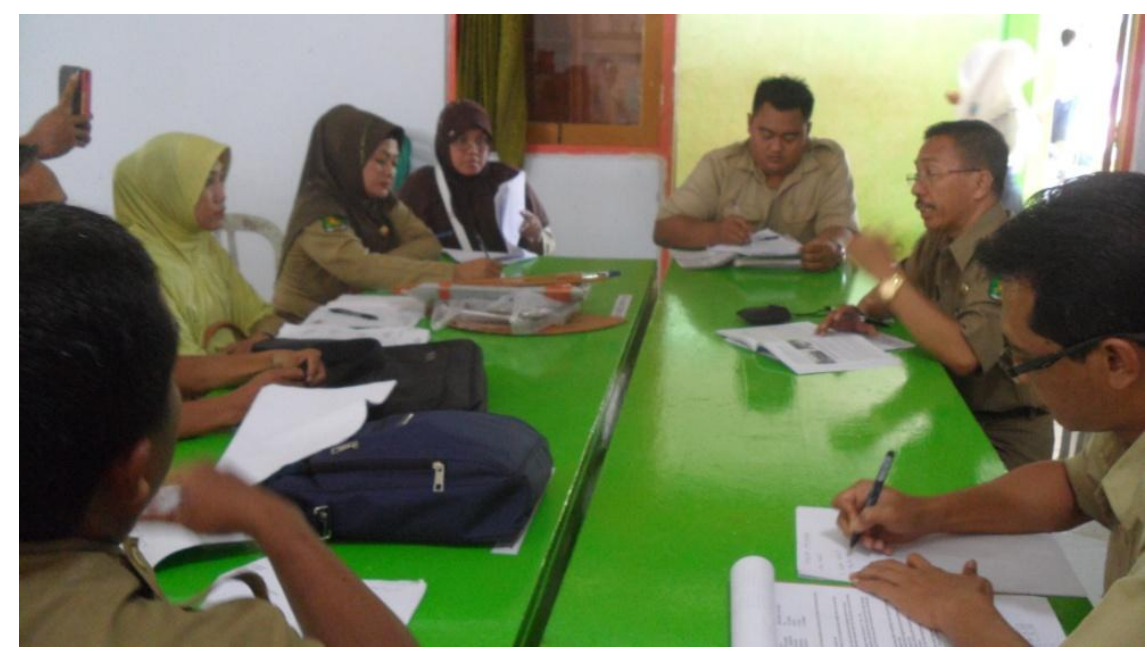

Gambar 11. Tahap SEE

Masukan-masukan dari pengamat dari hasil pengamatan dicatat oleh notulen dan semua difokuskan pada hasil dalam lembar pengamatan.

Kegiatan Lesson Study mata pelajaran IPA di Kelas VIII - C pelaksanaannya memberikan pengalaman yang sangat berharga, bahwa untuk membuat sebuah pembelajaran yang dikatakan berhasil diperlukan perencanaan yang sangat matang.Untuk itulah, rencana pembelajaran yang akan dibuat harus dapat memprediksi dan membuat alternatif solusi untuk semua kejadian yang mungkin akan terjadi selama kegiatan pembelajaran. Hal ini penting untuk mengantisipasi segala kemungkinan yang dapat menghambat pembelajaran yang akan diperoleh siswa.

Manfaat yang di dapat setelah guru mengimplementasikan Lesson Study di SMP Negeri 1 Kalianget adalah sebagai berikut :

Ada beberapa hal yang dirasakan para guru mengenai kegiatan ini, diantaranya yaitu:

\section{Kolektivitas}

Jika biasanya program perbaikan diupayakan oleh tiap individu, maka kegiatan Lesson Study justru mensyaratkan kebersamaan. Kesuksesan peserta didik dan proses belajar mengajar di kelas menjadi tanggung jawab bersama. Siklus "plan see do"pada kegiatan Lesson Study merupakan hasil musyawarah terbuka para guru.

2. Terpusat pada peserta didik dan proses belajar mengajar

Peserta didik dan proses belajar mengajar yang merupakan "hati" dari sebuah sekolah benar-benar diperhatikan. Pertanyaan-pertanyaan seperti; Apakah siswa dapat berpikir pada topik / materi pembelajaran? Siapakah siswa-siswa yang tidak dapat belajar pada pembelajaran saat ini? mengapa siswasiswa tersebut tidak dapat belajar pada saat ini? Untuk membuat siswa dapat belajar cara dan alat apa yang digunakan oleh guru open class? Apakah berhasil? Dan apakah kerja perseorangan atau kelompok? Dapat terjawab dalam kegiatan ini.

Guru-guru yang berperan sebagai observer memiliki kesempatan untuk mempelajari banyak hal dari guru yang melaksanakan proses belajar mengajar. Secara unik, kegiatan ini mewajibkan setiap observer untuk menuliskan tiga nilai positif dari guru ketika mengajar.

\section{Belajar dari rekan sejawat}

Belajar dari rekan sejawat dianggap lebih mudah daripada belajar pada pakar pendidikan yang membagikan ilmunya pada kegiatan pelatihan atau seminar. Belajar dari rekan sejawat, tantangan kesenjangan dari segi ilmu, pengalaman, budaya, dan usia lebih mudah disikapi. 
Kegiatan Lesson Study pun pada akhirnya memupuk para guru melakukan kerja keras berupa refleksi, inovasi, dan konsistensi pelaksanaan pembelajaran yang efektif. Rasanya malu bila tidak menyajikan yang terbaik pada siswa dan observer.

4. Berbasis sekolah atau mata pelajaran. Intensitas program MGMP tak mungkin dilaksanakan secara rutin di wilayah Kabupaten Sumenep. Sebab utama adalah jarak dan waktu.Lesson Study yang berbasis pada sekolah atau mata pelajaran membuat kegiatan ini mudah dan murah dari segi pelaksanaan.

Dengan demikian, fokus kegiatan lesson study adalah kajianpembelajaran sehingga dapat menemukan praktik terbaik, berdasarkan pengalaman-pengalaman yang diamati dalam beberapa tahapan pembelajaran yang dilakukan oleh guru.

\section{KESIMPULAN}

Lesson Study Berbasis Sekolah dapat memberikan jaminan hak belajar siswa dan membentuk hubungan saling belajar, saling mendengarkan serta saling mendukung dalam komunitas sekolah. Lesson Study Berbasis Sekolah dapat meningkatkan profesinalisme guru dan membentuk learning community di sekolah.

Pada prinsipnya pelaksanaan Lesson Study yang dilaksanakan di SMP Negeri 1 Kalianget memberikan efek positif pada peningkatan kualitas pembelajaran dan peningkatan profesionalisme guru secara bertahap dan berkelanjutan.

\section{DAFTAR PUSTAKA}

Saito, E., Imansyah, H. dan Ibrohim. 2005. Penerapan Studi Pembelajaran di Indonesia: Studi Kasus dari IMSTEP . Jurnal Pendidikan "Mimbar Pendidikan", No.3. Th. XXIV: 24-32.

\author{
Sudrajat,A.2008. "Lesson Study untuk \\ Meningkatkan Proses dan Hasil \\ Pembelajaran." \\ (http://akmadsudrajat.wordpress. \\ com/, diakses 6 Maret 2014).
}

